in her life and began her illustrious career as a university teacher. She received an M.A. in 1946 and completed her Ph.D. in 1949. She was promoted through the ranks and was the first woman to be given tenure and become a full professor in the politics department. She retired in 1986 and was designated Professor Emerita. During her 42 years at NYU she taught more than 30,000 students.

At her retirement party, a colleague quipped: "She paid all our salaries for years." He was referring to the fact that she taught very large classes, up to 275 students including many who were on the GI Bill of Rights. The politics department also recognized her by naming a seminar room and a student prize in her honor.

She was the first woman in the liberal arts to win the Great Teacher Award and won the "Golden Dozen" award (a choice by undergraduates of their 12 favorite professors) for six successive years. One had to be on campus to receive this award and she was not eligible for the 1965-1966 academic year because she had been awarded a Fulbright Professorship at the University of Innsbruck in Austria. During that year, she also lectured at the Universities of Graz and Salzburg and at the AustrianAmerican Gesellschaft in Vienna.

Professor Cooley was very active in university affairs. She was elected several times to the All-University Faculty Council and became the chairperson in 1975, another first for a woman. She was a member of the Graduate Dean's Advisory Committee, serving under five successive deans.

Despite her heavy teaching and committee schedules, she supervised 12 doctoral dissertations and was able to publish scholarly articles. Her publications included a 30-page article on "Teaching Social Science" in Steven M. Cahn's book Scholars Who Teach (1978), and a textbook, Government in American Society (1950), which she wrote with three colleagues. Her articles appeared in several journals including Social Science, American Journal of Legal History, Journal of the American Judicature Society, Western Political Quarterly, School and Society, American Political Science Review and the New York University Law Review. She also authored many reviews of books in the field of American government.

After her retirement, she continued to attend meetings of the current NYU Faculty Council which invites former chairpersons for their "institutional memories." She was very well known throughout the University. At the retire- ment party for a colleague in the history department in the spring of 2002, the honoree in addressing those present (about 100) said: "I want to acknowledge the presence of Prof. Cooley at this event. I have known, admired, and loved her for more than 50 years." Everyone in the room stood up and applauded.

In 1977, a former student and sitting judge conceived and organized a "Friends of Rita Nealon Cooley Association." The group assembled on October 19, 1997, at the home of another former student to honor their favorite professor and lifelong friend. Thirty-five in all attended the joyous occasion, traveling from Connecticut, Georgia, Maryland, Massachusetts, Oregon, and as far away as London. Included were an international financier, a noted author, a New York State Supreme Court Justice, and several university professors, as well as physicians, lawyers, and other professionals. Even the New York Times made note of the occasion, publishing a feature article on the gathering in its "City" section. Age spans of former students who attended ranged from 38 to 83; each recounted their relationship with Professor Cooley. She, in turn, regaled her audience with recollections of classes each had taken, papers written, and grades and critiques she had given them, dating as far back as 40 years. Her humor, dynamic personality, passion for her profession, and love for her students filled the room.

Rita Cooley died in October 2006. Her husband, Professor Hollis R. Cooley of the NYU's Courant Institute for Mathematical Sciences, had died in 1987. Her survivors include her stepson, a stepgranddaughter, and two nieces.

Rita Cooley was a legendary NYU Professor. May she rest in peace.

Farhad Kazemi New York University

\section{Michael Baruch Grossman}

Michael Baruch Grossman, 70, a political science professor whose specialty was the relationship between the president and the news media, died May 14, 2007, in Oakland, California, from complications arising from pancreatic cancer.

Grossman's scholarly work spanned the period of the evolution of the modern White House press corps beginning with the Franklin Roosevelt administration. In Portraying the President: The White House and the News Media, coauthored with Martha Joynt Kumar, they argued that the White House and the media are locked in a relationship of mutual need. The underlying cooperative elements of this relationship, although often obscured by visible and memorable clashes, provide the underlying structure. In addition, they contended, most presidents' problems with news organizations stem from their overestimation of their ability to change the rules governing the relationship. The unrealistic White House expectations about how the media should "behave" have often led to the president's inability to communicate effectively with the political and public partners that the media offers to him.

Michael Grossman was born in Boston, Massachusetts on August 17, 1936. He attended public schools in Brookline, MA and graduated from the U.S. Army Dependent High School in Frankfurt, Germany. At the time, his father was in Europe with the United States Information Agency. After receiving a B.A. from Oberlin College in 1957, he worked briefly at the Washington Post and served in the U.S. Army. He earned his Ph.D. in political science from Johns Hopkins University in 1968. From 19671970 , Grossman served as associate secretary for the American Association of University Professors, where he worked on problems involving due process, academic freedom issues, and faculty relations. Grossman left to become chairman of the department of political science at Towson University, where he served as chairman until 1977 and then taught in the department until 1993. He also taught political science and communications courses at Johns Hopkins, Goucher College, UC at Davis, Cal State East Bay, and Mills College. His last academic position was as a visiting professor at the University of California, Berkeley. He was the recipient of a Ford Foundation grant to fund research for Portraying the President, was a president of the National Capital Political Science Association, and an officer of the Presidency Research Group of the American Political Science Association.

His friends appreciated his warmth and strong support for them, his sense of humor, and his enthusiasm for baseball. Grossman is survived by his daughters Michele Cunningham of Chicago, and Rikki Edelman of Concord, California, and four grandchildren.

\section{Martha Joynt Kumar Towson University}

\section{John W. Lederle}

John W. Lederle, age 94, born in Royal Oak, Michigan in 1912, president of the University of Massachusetts, 1960-1970, died February 13, 2007. His wife of almost 69 years, Angie, died March 4th, both in Naples, Florida, 